\title{
PENGARUH VARIABEL MAKROEKONOMI TERHADAP RETURN INDEKS LQ 45 DAN PEFINDO 25
}

\section{MACROECONOMICS EFFECT ON LQ 45 AND PEFINDO 25 INDEX RETURN}

\author{
Dennis Nugroho Prakoso*)1, Muhammad Firdaus ${ }^{* *)}$, dan Trias Andati***) \\ *) Sekolah Bisnis, Institut Pertanian Bogor \\ Jl. Raya Pajajaran, Bogor 16151 \\ **) Departemen Ilmu Ekonomi, Fakultas Ekonomi dan Manajemen, Institut Pertanian Bogor \\ Jl. Agatis Kampus IPB Darmaga, Bogor 16680 \\ ${ }^{* * *)}$ PT. Adhimix Precast Indonesia \\ JL. Raya Pasar Minggu, No. 17 A, Pancoran, Jakarta, 12780
}

\begin{abstract}
Stock investment is one of the well-known types of investment. Investors want a positive return on the investment they make, in fact, getting a return on investment is very difficult. One way to reduce losses is to use an index, the fluctuating index movement is the influence of macroeconomic factors such as the BI rate, CPI, the exchange rate of the US dollar, Brent oil prices, and the gold price. The indexes that are often used by investors are the $L Q 45$ and Pefindo 25 indexes. The LQ 45 index is used as an indicator in this study to describe the "behavior" of large capitalization stocks and the Pefindo 25 index is used to represent small and medium-sized companies. This research is intended to see the effect of macroeconomic factors on the return of both indices. The method used in this study is the Ordinary Least Square $(O L S)$ model. The results obtained in this study show that the BI rate macroeconomic factors, exchange rates, gold prices, oil prices have a positive influence on the $L Q 45$ index except the exchange rate which has a negative effect on the Index. The Pefindo 25 index is influenced by the BI rate, CPI, and oil prices. This result shows that if investors invest in the LQ 45 index, it is better to pay attention to the BI rate, gold prices, oil prices, and the exchange rate as the basis for making decisions on investments made. At the Pefindo index 25 investors should pay attention to the BI rate, CPI and oil prices as the basis for making investment decisions.
\end{abstract}

Keywords: index, $L Q 45$, macroeconomics, Pefindo 25, IHK

\begin{abstract}
Abstrak: Investasi saham merupakan salah satu jenis investasi yang terkenal. Investor menginginkan pengembalian yang positif dari investasi yang dilakukannya, pada kenyataannya memperoleh keuntungan dalam investasi sangat sulit. Salah satu cara untuk mengurangi kerugian adalah dengan menggunakan index, pergerakan indeks yang berfluktuatif merupakan pengaruh dari faktor-faktor makroekonomi seperti BI rate, IHK, Kurs tukar Rupiah-Dollar AS, harga minyak Brent, dan Harga emas. Indeks-indeks yang sering digunakan oleh inestor adalah indeks LQ 45 dan Pefindo 25. Indeks LQ 45 yang digunakan sebagai indikator pada penelitian ini untuk menggambarkan "perilaku" saham-saham kapitalisasi besar dan indeks Pefindo 25 digunakan untuk mereprensentasikan perusahaan kecil dan menengah. Penelitian ini ditujukan untuk melihat mengaruh faktor makroekonomi pada return kedua indeks. Metode yang digunakan dalam penelitian ini adalah model Ordinary Least Square (OLS). Hasil yang diperoleh dalam penelitian ini menunjukan bahwa faktor makroekonomi BI rate, nilai tukar, harga emas, harga minyak memiliki pengaruh positif terhadap indeks LQ 45 kecuali nilai tukar yang memiliki pegaruh negatif terhadap Indeks. Indeks Pefindo 25 dipengaruhi oleh BI rate, IHK, dan harga minyak. Hasil ini menunjukan bila investor berinvestasi pada indeks LQ 45 lebih baik memperhatikan BI rate, harga emas, harga minyak, dan nilai kurs tukar sebagai dasar pengambilan keputusan investasi yang dilakukannya. Pada indeks Pefindo 25 investor sebaiknya memperhatikan BI rate, IHK dan harga minyak sebagai dasar pengambilan keputusan investasi.
\end{abstract}

Kata kunci: indeks, LQ 45, makroekonomi, Pefindo 25, IHK

\footnotetext{
${ }^{1}$ Alamat Korespondensi:

Email: dennis.n.prakoso@gmail.com
} 


\section{PENDAHULUAN}

Faktor-faktor makroekonomi memberikan pengaruh sangat besar terhadap fluktuasi tingkat pengembalian saham-saham perusahaan yang tercermin pada pergerakan harga saham di pasar modal. Pergerakanpergerakan yang melebihi normal, seperti yang diakibatkan oleh krisis ekonomi global, dari variabelvariabel makro akan menciptakan goncangan tertentu pada pasar modal, yang memengaruhi nilai tingkat pengembalian saham-saham pada pasar modal (Damayanti, 2014). Pergerakan dalam harga saham dalam pasar yakni IHSG membuat investor mengalami kesulitan dalam mengambil keputusan dalam investasi. Untuk membantu membaca pergerakan indeks diperlukan alat bantu dengan menggunakan faktor makroekonomi. Selain IHSG indeks yang sering dilihat oleh investor dalam melakukan investasinya adalah Indeks LQ 45 yang digunakan sebagai indikator pada penelitian ini untuk menggambarkan "perilaku" saham-saham kapitalisasi besar. Selain indeks LQ 45 indeks lain yang digunakan adalah indeks PEFINDO 25, indeks PEFINDO 25 merupakan indeks yang beranggotakan emiten-emiten yang tergolong Small and Medium Enterprises (SME) dengan minimal aset lima triliun rupiah. Indikasi anomali perlu dilihat pada indeks berkapitalisasi berbeda karena pasar, terutama investor-investor risk lover, lebih memilih untuk melakukan trading pada saham-saham lapis kedua karena kelompok saham ini menawarkan return yang lebih tinggi daripada saham-sahamberkapitalisasibesar, namun dengan risiko yang lebih besar pula (Switzer, 2012). Tidak ada definisi pasti mengenai saham-saham lapis kedua, namun secara umum investor merujuk saham lapis kedua sebagai saham-saham pilihan kedua terbaik setelah saham-saham blue chips seperti LQ 45. Pergerakan return dari IHSG, LQ 45, dan Pefindo 25 Selengkapanya pada Gambar 1.
Gambar 1 menunjukan pergerakan return dari LQ 45 dan Pefindo 25 yang menyerupai pergerakan return IHSG. Di Indonesia kebijakan tingkat suku bunga dikendalikan secara langsung oleh Bank Indonesia melalui BI Rate. BI Rate merupakan respon bank sentral terhadap tekanan inflasi ke depan agar tetap berada pada sasaran yang telah ditetapkan. Perubahan BI Rate sendiri dapat memicu pergerakan di pasar saham Indonesia. Penurunan BI Rate secara otomatis akan memicu penurunan tingkat suku bunga kredit maupun deposito. Bagi para investor, dengan penurunan tingkat suku bunga deposito, akan mengurangi tingkat keuntungan yang diperoleh bila dana yang mereka miliki diinvestasikan dalam bentuk deposito. Selain itu dengan penurunan suku bunga kredit, biaya modal akan menjadi kecil. Hal ini dapat mempermudah perusahaan untuk memperoleh tambahan dana dengan biaya yang murah untuk meningkatkan produktivitasnya. Peningkatan produktivitas akan mendorong peningkatan laba, hal ini dapat menjadi daya tarik bagi para investor untuk berinvestasi di pasar modal.

Selain BI Rate faktor lain yang sering digunakan adalah harga emas. emas merupakan salah satu komoditi penting yang dapat memengaruhi pergerakan bursa saham. Hal ini didasari bahwa emas merupakan salah satu alternatif investasi yang cenderung aman dan bebas resiko (Sunariyah, 2006). Nilai ini mengikuti standar internasional yang berlaku nilainya pada hari penjualan lagi. Oleh sebab itu, kenaikan harga emas akan mendorong penurunan indeks harga saham karena investor yang semula berinvestasi di pasar modal akan mengalihkan dananya untuk berinvestasi di emas yang relatif lebih aman daripada berinvestasi di bursa saham. Pergerakan dari perubahan harga emas dengan return dari IHSG Selengkapanya pada Gambar 2.

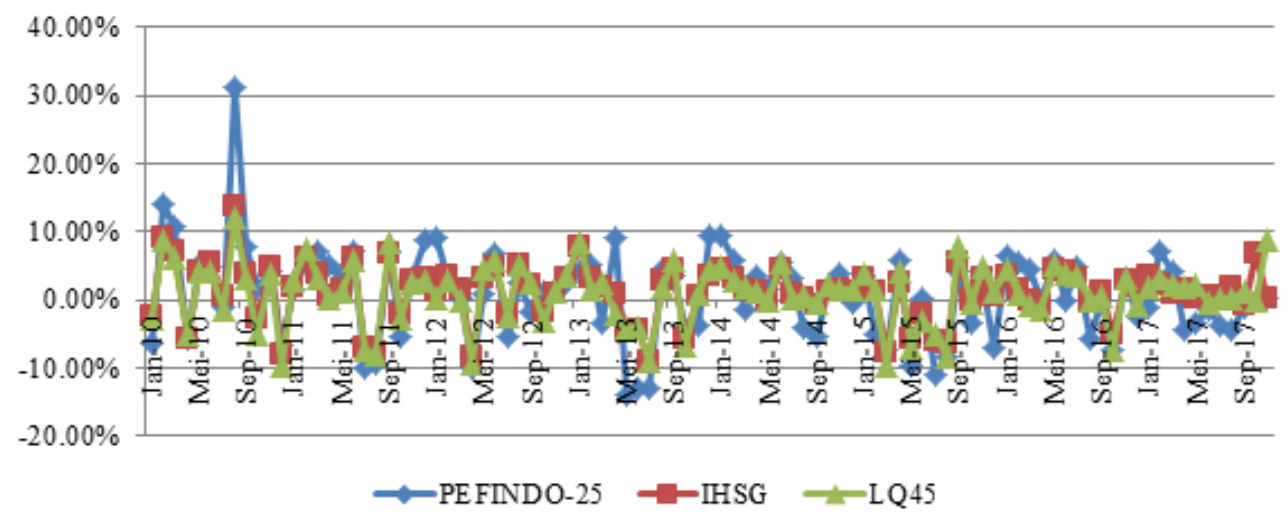

Gambar 1. Pergerakan return IHSG, LQ 45, dan Pefindo 25 Periode Januari 2010 - Desember 2017 


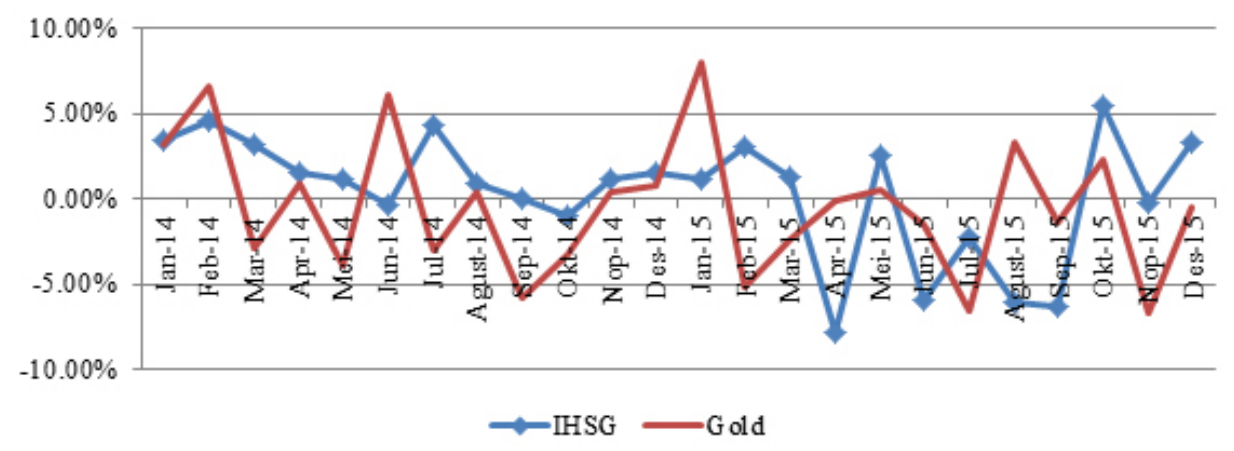

Gambar 2. Pergerakan Return IHSG dan perubahan emas Periode Januari 2014 - Desember 2015

Pada Gambar 2 menggambarkan pergerakan dari harga emas dengan return dari IHSG. Pada periode 20142015 merupakan periode dimana harga emas sedang menurun secara drastis, harga emas yang sebelumnya berada pada kisaran harga 1300US\$/Ons menjadi 1100US\$/Ons. Penurunan harga emas ini merupakan respon dari semakin baiknya tingkat pertumbuhan ekonomi AS yang semakin membaik (Detikfinance, 2014)

Komoditas lain yang dianggap memengaruhi pergerakan IHSG adalah harga minyak bumi. Bahan bakar minyak (BBM) merupakan komoditas yang memegang peranan sangat vital dalam semua aktivitas ekonomi. Dampak langsung perubahan harga minyak ini adalah perubahan-perubahan biaya operasional yang mengakibatkan tingkat keuntungan kegiatan investasi langsung terkoreksi. Terjadinya hubungan timbal balik antara naiknya biaya produksi dan turunnya daya beli masyarakat berarti memperlemah perputaran roda ekonomi secara keseluruhan di Indonesia. Kondisi ini dapat memengaruhi iklim investasi secara keseluruhan baik dalam jangka pendek maupun jangka panjang. Dalam jangka pendek naiknya harga BBM tersebut disikapi oleh pelaku pasar, khususnya pelaku pasar modal sebagai pusat perputaran dan indikator investasi (Zunara, 2014). Pergerakan harga minyak bumi brent dengan IHSG Selengkapanya pada Gambar 3.

Periode 2014-2015 merupakan periode harga minyak menurun secara drastis, hal ini disebabkan supply yang berlebih akibat negara-negara anggota OPEC yang menguasai $40 \%$ perdagangan minyak bumi tidak mengurangi jumlah minyak yang diproduksinya (BBC, 2014). Langkah yang diambil anggota OPEC ini menyebabkan supply minyak bumi meningkat. Bergerak menurunnya harga seharusnya mendorong kegiatan investasi tetapi terlihat pada gambar pergerakan return IHSG cenderung bergerak datar. Penelitian ini menganalisis dua indeks return sekaligus yaitu LQ 45 dan Pefindo 25, sedangkan penelitian lain umumnya membahs kedua indeks tersebut secara terpisah. Selain kedua indeks saham tersebut penelitian ini juga menganalisis hubungan variabel makroekonomi yang merupakan variabel penting untuk diteliti saat ini, yaitu: BI Rate, Indeks Harga Konsumen, kurs tukar Rupiah terhadap Dollar AS, Harga minyak Brent, dan Harga emas.

Pergerakan LQ 45 dan Pefindo 25 yang berfluktuatif dan dinamis sesuai dengan kondisi makroekonomi, memberikan kesempatan bagi investor untuk memperloeh keuntungan dari investasi saham, namun terdapat juga kemungkinan kerugian yang dapat dialami oleh investor. Keuntungan yang dapat diperloleh investor yakni return baik dari selisih harga jual dan harga beli tetapi juga dari dividen yang diperoleh selama investasi. Keuntungan atau return yang diperoleh investor ini juga diikuti oleh peningkatan tingkat kerugian atau resiko yang mungkin akan dialami oleh investor selama masa investasi, kerugian atau resiko yang ditanggung oleh investor dapat timbul karena investor kurang dapat memanfaat kan informasi yang tersedia dan cenderung bergerak mengikuti investor lain. Hasan (2011) perdagangan saham merupakan refleksi dari kegiatan ekonomi seharusnya diprengaruhi oleh kondisi ekonomi, mamun informasi yang tersedia tidak tercermin secara benar dalam harga saham yang ada pada pasar dan investor melakukan investasi tidak dengan pemikiran yang rasional. Untuk menghindari dari keputusan yang kurang rasional tersebut investor dapat menggunakan alat bantu dalam menganalisa investasi yang dilakukannya. Salah satu metode yang dapat digunakan dengan menggunakan variable-variabel makro ekonomi untuk memprediksi pergerakan dari LO45 dan Pefindo 25. 
Data variabel makroekonomi yang ada memiliki pengaruh pada pergerakan LQ 45 dan Pefindo 25, sehingga perlu diketahui variabel makroekonomi manakah yang memberikan pengaruh yang lebih besar pada pergerakan IHSG. Faktor-faktor makro ekonomi yang sering dianalisis karena diduga secara relevan memengaruhi nilai saham secara umum diantaranya adalah harga minyak (Fatima dan Bashir, 2014), harga emas (Phoong et al. 2013), nilai tukar mata uang (Vanita dan Khushboo, 2015), tingkat suku bunga (Eita, 2014), dan inflasi (Eita, 2012). Tujuan penelitian ini adalah untuk menganalisis pengaruh variabel makroekonomi (Tingkat suku bunga Bank Indonesia, Kurs Tukar Rupiah dengan Dollar AS, Indeks Harga konsumen, Harga Emas Dunia, Harga Minyak Brent) terhadap pergerakan Indeks LQ 45; menganalisis pengaruh variabel makroekonomi (Tingkat suku bunga Bank Indonesia, Kurs Tukar Rupiah dengan Dollar AS, Indeks Harga konsumen, Harga Emas Dunia, Harga Minyak Brent) terhadap pergerakan indeks Pefindo 25; merumuskan saran pengambilan keputusan terkait investasi saham di Indonesia kepada investor.

Ruang lingkup dalam penelitian ini adalah pada level indeks, yaitu Indeks LQ 45 dan Pefindo 25, bukan pada level emiten yang ada di dalamnya. Fokus penelitian ini adalah pergerakan return Indeks LQ 45 dan Pefindo 25 dan analisis faktor-faktor yang diduga secara relevan memengaruhinya. Faktor-faktor yang dianalisis adalah faktor eksternal faktor yang digunakan yaitu tingkat suku bunga Bank Indonesia (BI Rate), harga minyak mentah, nilai tukar IDR terhadap USD, harga emas, Indeks Harga Konsumen. Analisis faktor internal tidak dilakukan karena ruang lingkupnya bukan pada level emiten.

\section{METODE}

Data yang digunakan dalam penelitian ini adalah data sekunder. Data yang digunakan adalah bulanan. Data yang digunakan terdiri dari data indeks LQ 45 dan Pefindo 25, harga minyak dunia, harga emas, nilai tukar mata uang rupiah terhadap Dollar Amerika Serikat, tingkat suku bunga Bank Indonesia, dan Indeks Harga Konsumen. Data indeks LQ 45 dan Pefindo 25 bersumber dari YahooFinance, data suku bunga Bank Indonesia dan kurs tukar Rupiah dan Dollar AS diperoleh dari Bank Indonesia(www.bi.go.id), data Indeks Harga Konsumen bersumber dari Biro Pusat Statistik (BPS), harga minyak Brent, dan harga emas dunia diperoleh dari situs online Investing.com(www. Investing.com). Semua data yang digunakan merupakan periode bulanan, periode yang digunakan adalah Januari 2010 sampai dengan Desember 2017. Data variabel makroekonomi dalam penelitian ini diolah menjadi bentuk yang sama dengan return dari indeks LQ 45 dan Pefindo 25. Metode yang digunakan dalam Penelitian ini adalah model Ordinary Least Square (OLS).

Setelah melalui tahapan pengujian asumsi klasik maka dapat disimpulkan model yang menggambarkan fungsi dari return LQ 45 dan Pefindo 25 yang dianalisis dengan faktor makroekonomi yang telah diungkapkan dalam perumusan masalah (Suku Bunga Bank Indonesia dilambangkan dengan SBI, nilai tukar Rp/US\$ sebagai EX, Indeks harga konsumen sebagai IHK, tingkat suku bunga Amerika Serikat sebagai FED, harga emas dunia sebagai G, dan harga minyak mentah Brent sebagai OB. Berikut ini merupakan fungsi yang akan menjelaskan return:

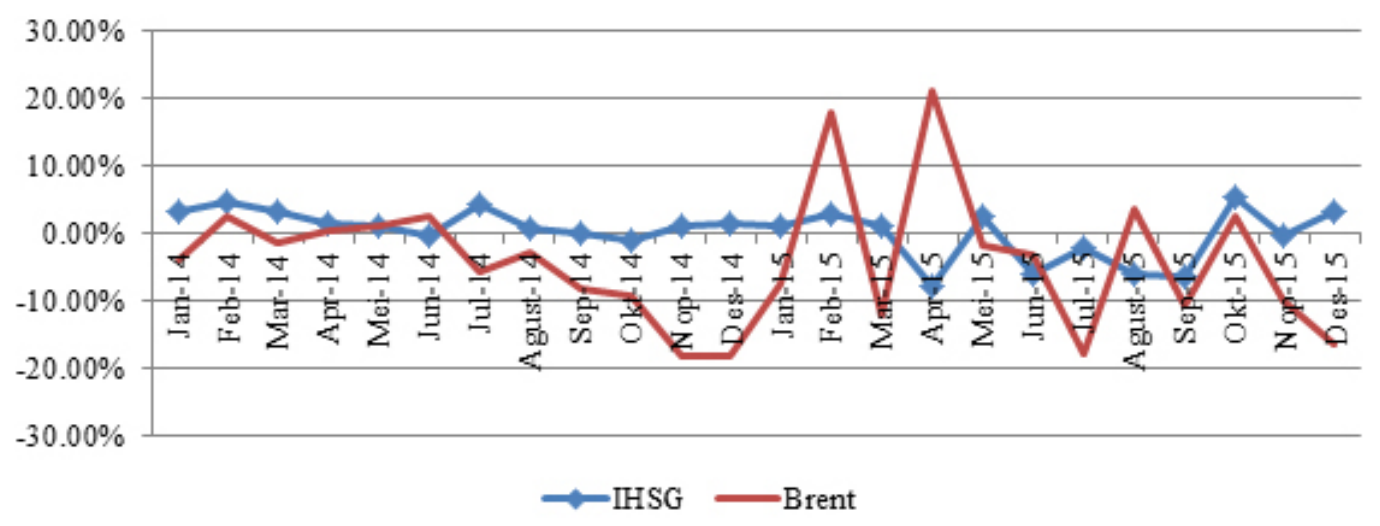

Gambar 3. Pergerakan return IHSG dan perubahan Brent Periode Januari 2014 - Desember 2015 
Model 1 menggambarkan hubungan antara return LQ 45 dengan variabel-variabel makroekonomi yang digunakan sebagi berikut:

$r_{t} 1=a_{t}+b_{S B I} S B I_{t}+b_{E X} E_{t}+b_{C P I} C P I_{t}+b_{G} G_{t}+b_{O B} O B_{t}+e_{t}$

Keterangan: $\mathrm{r}_{\mathrm{t}} 1$ (Expected return LQ 45; $\mathrm{b}$ (beta variabel makroekonomi); EX (Kurs tukar Rupiah-Dollar AS periode $\mathrm{t}$ ); $\mathrm{CPI}_{\mathrm{t}}$ (Indeks Harga Konsumen periode $\mathrm{t}$ ); $\mathrm{G}_{\mathrm{t}}$ (Harga Emas periode t); OBt (Harga Minyak Brent periode $\mathrm{t}) ; \mathrm{e}_{\mathrm{t}}$ (Error term)

Berdasarkan pada model 1 mengenai hubungan variabel makroekonomi dengan expected return LQ 45, dapat dibentuk hipotesis sebagai berikut:

H0 : Perubahan tingkat suku bunga bank Indonesia tidak berpengaruh negatif dan signifikan terhadap return LQ45

H1 : Perubahan tingkat suku bunga bank Indonesia berpengaruh negatif dan signifikan terhadap return LQ45

H0 : Perubahan kurs Rupiah terhadap Dollar AS tidak berpengaruh negatif dan signifikan terhadap return LQ45

H1 : Perubahan kurs Rupiah terhadap Dollar AS berpengaruh negatif dan signifikan terhadap return LQ45

H0 : Perubahan Indeks Harga Konsumen tidak berpengaruh negatif dan signifikan terhadap return LQ45

H1 : Perubahan Indeks Harga Konsumen berpengaruh negatif dan signifikan terhadap return LQ45

H0 : Perubahan Harga emas dunia tidak berpengaruh negatif dan signifikan terhadap return LQ45

H1 : Perubahan Harga emas dunia berpengaruh negatif dan signifikan terhadap return LQ45

H0 : Perubahan Harga minyak dunia (Brent) berpengaruh negatif dan signifikan terhadap return LQ45

H1 : Perubahan Harga minyak dunia (Brent) berpengaruh negatif dan signifikan terhadap return LQ45

Model 2 menggambarkan hubungan antara return Pefindo 25 dengan variabel-variabel makroekonomi yang digunakan sebagi berikut: $r_{t} 2=a_{t}+b_{S B I} S B I_{t}+b_{E X} E_{t}+b_{C P I} C P I_{t}+b_{G} G_{t}+b_{O B} O B_{t}+e_{t}$

Keterangan: $\mathrm{r}_{\mathrm{t}} 2$ (Eexpected return Pefindo 25); b (beta variabel makroekonomi); $\mathrm{EX}_{\mathrm{t}}$ (Kurs tukar RupiahDollar AS periode t); $\mathrm{CPI}_{\mathrm{t}}$ (Indeks Harga Konsumen periode $\mathrm{t}$ ); $\mathrm{G}_{\mathrm{t}}$ (Harga Emas periode $\mathrm{t}$ ); $\mathrm{OB}_{\mathrm{t}}$ (Harga Minyak Brent periode $\mathrm{t}) ; \mathrm{e}_{\mathrm{t}}($ Error term).

Berdasarkan pada model 2 mengenai hubungan variabel makroekonomi dengan expected return Pefindo 25, dapat dibentuk hipotesis sebagai berikut:

H0 : Perubahan tingkat suku bunga bank Indonesia tidak berpengaruh negatif dan signifikan terhadap return Pefindo 25

H1 : Perubahan tingkat sukubunga bank Indonesia berpengaruh negatif dan signifikan terhadap return Pefindo 25

H0 : Perubahan kurs Rupiah terhadap Dollar AS tidak berpengaruh negatif dan signifikan terhadap return Pefindo 25

H1 : Perubahan kurs Rupiah terhadap Dollar AS berpengaruh negatif dan signifikan terhadap return Pefindo 25

H0 : Perubahan Indeks Harga Konsumen tidak berpengaruh negatif dan signifikan terhadap return Pefindo 25

H1 : Perubahan Indeks Harga Konsumen berpengaruh negatif dan signifikan terhadap return Pefindo 25

H0 : Perubahan Harga emas dunia tidak berpengaruh negatif dan signifikan terhadap return Pefindo 25

H1 : Perubahan Harga emas dunia berpengaruh negatif dan signifikan terhadap return Pefindo 25

H0 : Perubahan Harga minyak dunia (Brent) tidak berpengaruh negatif dan signifikan terhadap return Pefindo 25

H1 : Perubahan Harga minyak dunia (Brent) berpengaruh negatif dan signifikan terhadap return Pefindo 25

\section{Pengujian Asumsi Klasik}

Estimator OLS adalah estimator fungsi regresi tak bias linear terbaik atau best linear unbiased estimator (BLUE) karena model regresi yang dihasilkan dengan metode OLS berbentuk linear, tak bias, dan mempunyai varian terendah dalam kelompok penaksir dari sebuah model (Gujarati dan Porter, 2009). Untuk mengetahui 
sifat-sifat OLS tersebut apakah terdapat pada model yang dihasilkan maka dilakukan pengujian-pengujian sebagai berikut:

\section{Uji Normalitas}

Alat uji normalitas yang akan digunakan pada penelitian ini adalah uji Jarque-Berra (Gujarati dan Porter, 2009). Bila nilai Jarque-Berra lebih kecil dari pada tingkat error yang ditentukan maka error term belum terdistribusi normal, bila nilai Bila nilai Jarque-Berra lebih besar dari pada tingkat error yang ditentukan maka error term terdistribusi normal (Gujarati dan Porter, 2009). Pelangaran pada asumsi akan terlihat pada besarnya nilai R2 dan tingginya nilai t, tetapi variabel tidak berhubungan (Asteriou dan Hall, 2007).

\section{Uji Autokorelasi}

Autokorelasi merupakan kondisi adanya korelasi antar variabel bebas. Autokorelasi menyebabkan model atau penaksir OLS menjadi tidak efisien karena tidak mempunyai varians terkecil dan uji signifikansi menjadi tidak andal (Gujarati, 2009). Autokorelasi diidentifikasi melalui Uji Durbin-Watson. Bila nilai Durbin-Watson yang didapat berada pada daerah tanpa keputusan (4- dU $<\mathrm{d}<4-\mathrm{dL}$ ) maka akan dilakukan uji lanjutan yaitu Breusch Godfrey Serial Correlation LM Test. Pada uji tersebut identifikasi autokorelasi menggunakan nilai Prob, bila nilai Prob $<\alpha$ (tingkat error yang ditentukan) maka terdapat autokorelasi antar variabel bebas, sebaliknya bila nilai Prob $>\alpha$ maka tidak terdapat autokorelasi antar variabel bebas (Maruddani et al. 2008).

\section{Uji Multikolinearitas}

Multikolinearitas merupakan hubungan sempurna atau hubungan linear antara variabel penjelas (variabel independen). Efek multikolinearitas diantaranya adalah: tingginya varians dan kovarians, t-rasio cenderung tidak signifikan tetapi R2 cenderung tinggi, sensitifitas tinggi. Ketiadaan multikolinearitas merupakan asumsi keenam dari asumsi multivariabel. Cara menguji multikolinearitas diantaraya adalah dengan uji korelasi antara dua regresor, bila hubungan lebih dari 0,8 maka terdapat masalah multikolinearitas (Gujarati, 1995).

\section{Uji Heteroskedastisitas}

Uji Heteroskedastisitas bertujuan menguji apakah dalam model regresi terjadi ketidaksamaan variance dari residual satu pengamatan ke pengamatan yang lain. Jika variance dari residual satu pengamatan ke pengamatan lain tetap, maka disebut Homokedastisitas dan jika berbeda disebut heteroskedastisitas. Kebanyakan data ini menghimpun data yang mewakili berbagai ukuran (kecil, sedang, dan besar). Akibat terjadinya heteroskedastisitas maka setiap terjadi perubahan pada variabel terikat mengakibatkan errornya (residual) juga berubah sejalan atau kenaikan atau penurunannya. Dengan kata lain konskuensinya apabila variabel terikat bertambah maka kesalahan juga akan bertambah (Gujarati, 1995).

Kerangka penelitian dimulai dari terjadinya gejolak harga emas dan minyak Brent pada pasar internasional memengaruhi pergerakan Indeks Saham LQ 45 dan Pefindo 25. Indeks Saham LQ 45 dan Pefindo 25 merupakan cerminan dan acuan dalam berinvestasi oleh Investor, Indeks Saham LQ 45, dan Pefindo 25 dipengaruhi oleh faktor makroekonomi. Faktor makroekonomi yang memengaruhi pergerakan kedua indeks tersebut adalah BI Rate, Nilai tukar RupiahDollarAS, Indeks Harga Konsumen, Harga Emas, Harga minyak Brent, informasi yang didapat tersebut kemudian dapat diolah sebagai dasar dalam pengambilan keputusan investasi. Keputusan yang diinginkan oleh investoradalahkeputusanyangmemberikankeuntungan dalam investasi yang dilakukan baik pada LQ 45 dan Pefindo 25, keuntungan yang diinginkan inilah yang disebut dengan return. Pengolahan informasi dalam penelitian ini menggunakan metode Ordinary Least Square (OLS) yang akan menghasilkan gambaran bagaimana hubungan antara variabel BI Rate, Nilai tukar Rupiah-DollarAS, Indeks Harga Konsumen, Harga Emas, dan Harga minyak Brent terhadap return dari indeks LQ 45 dan Pefindo 25. Kerangka pemikiran penelitian selengkapnya pada Gambar 4.

\section{HASIL}

\section{Pengaruh Variabel Makro Ekonomi Terhadap Pergerakan Indeks LQ 45}

Berdasarkan pada model pertama yakni pengaruh faktor makroekonomi terhadap return LQ 45. Output menunjukkan bahwa R2 $=0.6602$. Artinya, sebesar 
$66,02 \%$ proporsi keragaman variabel Return yang dapat dijelaskan oleh variabel makroekonomi dan sisanya sebesar 33,98\%. Pengaruh faktor makroekonomi terhadap return LQ 45 Selengkapanya pada Tabel 1.

BI Rate adalah suku bunga kebijakan yang mencerminkan sikap atau stance kebijakan moneter yang ditetapkan oleh bank Indonesia dan diumumkan kepada publik. Bank Indonesia melakukan penguatan kerangka operasi moneter dengan memperkenalkan suku bunga acuan atau suku bunga kebijakan baru, yaitu BI 7-Day Repo Rate, yang akan berlaku efektif sejak 19 Agustus 2016 (Bank Indonesia).

Pada hasil yang ditemukan dalam penelitian ini BI Rate memiliki pengaruh positif terhadap return dari LQ 45. Pengaruh BI Rate pada Return LQ 45 sebesar 0.318979, hasil ini menunjukan kenaikan $1 \%$ tingkat suku bunga acuan yakni BI Rate akan memengaruhi pergerakan Return LQ 45 sebesar 0.3189. Hasil ini menunjukan BI Rate berpengaruh Positif dan signifikan terhadap return LQ 45, pengaruh positif dari BI Rate ini tidak sesuai dengan penelitian Nugroho (2008), Prasetiono (2010), dan Suwandy (2014) menyebutkan tingkat suku bunga berpengaruh negatif terhadap return saham. Pengaruh positif pada return LQ 45 dipengaruhi oleh besarnya market capitalization sektor keuangan yang terdaftar dalam indeks LQ 45 hasil penelitian ini sesuai dengan penelitian yang dilakukan oleh Hasan (2010), Butt et al. (2010), serta Benakovic dan Posedol (2010).

Variabel makroekonomi berikutnya adalah kurs tukar Rupiah-Dollar AS. Madura (2000) menyebutkan bahwa nilai kurs adalah harga tukar dari satu mata uang ke mata uang lainnya dan valuta asing (valas) atau Foreign Exchange (FOREX). Berdasarkan pada hasil yang ada return indeks baik LQ 45 dipengaruhii secara negatif oleh faktor makroekonomi yakni kurs tukar RupiahDollar AS. Return LQ 45 dipegaruhi sebesar 0.758113 , yang dapat diartikan kenaikan $1 \%$ kurs tukan akan menurunkan return LQ 45 sebesar $0.75 \%$. Pengaruh negatif dan signifikan kurs pada return LQ 45 sejalan dengan penelitian oleh Vanita dan Khushboo (2015) menemukan hubungan negatif dan signifikan antara nilai tukar dengan harga saham di Rusia, India, dan Afrika Selatan. Hal ini terjadi karena saham kapitalisasi besar dalam LQ 45 banyak melakukan transaksi dengan pihak asing dalam kegiatan usahanya. Perubahan ini menyebabkan keuntungan yang diperoleh perusahaan semakin kecil sehingga berpengaruh pada performa perusahaan.

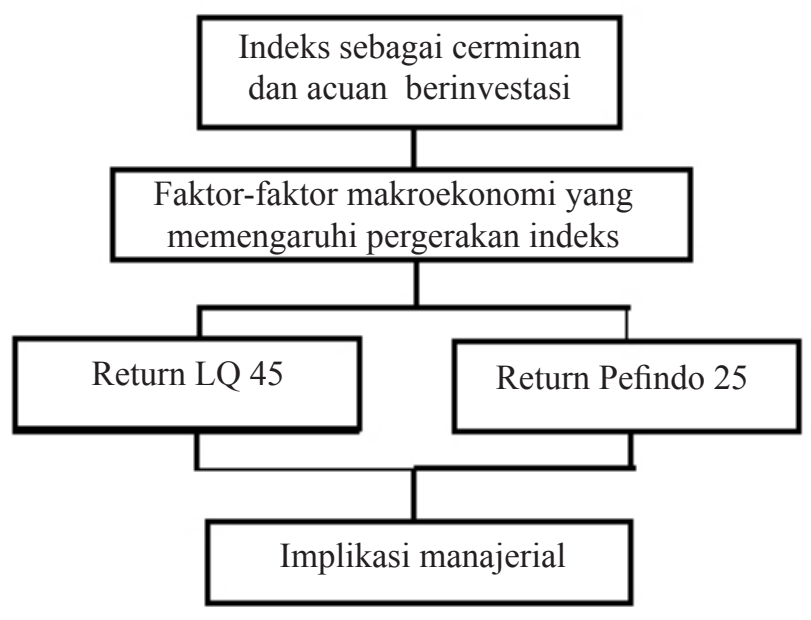

Gambar 4. Kerangka pemikiran penelitian

Tabel 1, Pengaruh faktor makroekonomi terhadap return LQ 45

\begin{tabular}{lcccc}
\hline Variable & Coefficient & Std, Error & $t$-Statistic & Prob, \\
\hline C & 6,408676 & 0,546325 & 11,73052 & 0,0000 \\
BI & 0,318979 & 0,169367 & 1,883361 & $0,0660^{*}$ \\
KURS & $-0,758113$ & 0,202526 & $-3,743293$ & $0,0005^{* *}$ \\
IHK & 0,467442 & 0,793004 & 0,589457 & 0,5584 \\
GOLD & 0,195572 & 0,093304 & 2,096063 & $0,0416^{* *}$ \\
OIL & 0,171638 & 0,057169 & 3,002298 & $0,0043^{* *}$ \\
\hline
\end{tabular}

*) nyata pada taraf $10 \%$; **) nyata pada taraf $5 \%$ 
Indeks Harga Konsumen dapat digunakan sebagai perwakilan dari inflasi, karena inflasi menyebabkan harga bahan baku meningkat dan pergeseran kebutuhan masyarakat menjadi kebutuhan konsumsi sehingga menyebabkan harga saham menjadi turun (Benakofic dan Posedol, 2010) dan diperkuat oleh penelitian Mubarok (2014) dan Utami (2015). Hasil dari penelitian ini menemukan bahwa indeks harga konsumen berpengaruh positif. Return LQ 45 dipengaruhi sebesar 0,467442 , pengaruh ini memiliki arti return LQ 45 akan mengalami peningkatan sebesar $0,467 \%$ bila Indeks Harga Konsumen meningkat sebanyak 1\%. Namun pada return LQ 45 menunjukan hasil yang tidak signifikan.

Harga Emas Dunia Menurut Handiani (2014) Emas merupakan jenis investasi yang diminati investor karena memiliki tingkat resiko yang relatif rendah, berfungsi sebagai pelindung kekayaan dan tidak terpengaruh oleh inflasi (zero inflation). Kenaikan harga emas dunia akan membuat investor lebih tertarik untuk berinvestasi pada emas daripada saham. Return indeks baik LQ 45 dipengaruhi secara positif oleh harga emas. Return LQ 45 dipengaruhi sebesar 0,195572, hal ini berarti return dari LQ 45 akan meningkat sebesar 0,196\% bila harga emas meningkat sebanyak 1\%. Dalam hasil dapat dilihat hanya return LQ 45 yang dipengaruhi secara signifikan pada taraf keyakinan 5\%. Pengaruh positif dan signifikan ini berlawanan dengan penelitian Handiani (2014) dan Monjazeb dan Shakerian (2014) yang menyatakan harga emas berpengaruh negatif terhadap return saham. Pengaruh positif dan signifikan ini sejalan dengan penelitian yang dilakukan oleh Horng dan Huang (2014) yang menyatakan harga emas berpengaruh positif. Pengaruh positif ini terjadi akibat investor memindahkan investasinya dalam bentuk emas kedalam bentuk saham dalam portofolio investasi yang dimilikinya.
Bahan bakar minyak (BBM) merupakan komoditas yang memegang peranan sangat vital dalam semua aktivitas ekonomi. Efek langsung yang dapat dirasakan adalah menurunnya keuntungan yang diperoleh akibat meningkatnya biaya-biaya operasional (Zunara, 2014). Return dari LQ 45 dipengaruhi secara positif oleh harga minyak Brent. Return LQ 45 dipengaruhi sebesar 0,171638. Hasil ini menunjukan kenaikan harga minyak Brent akan menaikan return LQ 45 sebesar $0,171 \%$. Hasil ini sejalan dengan penelitian yang dilakukan oleh Prasetiono (2010) yang menyatakan pergerakan positif ini disebabkan karena negara Indonesia merupakan negara penghasil minyak, sehingga dengan adanya kenaikan harga minyak akan meningkatkan pertumbuhan ekonomi yang kemudian akan meningkatkan pendapatan masyarakat yang pada akhirnya meningkatkan permintaan akan produk perusahaan dan harga saham.

\section{Pengaruh Variabel Makro Ekonomi Terhadap Pergerakan Indeks Pefindo 25}

Berdasarkan pada model kedua yakni pengaruh faktor makroekonomi terhadap return Pefindo 25. Output menunjukkan bahwa R2 $=0,755857$. Artinya, sebesar $75,58 \%$ proporsi keragaman variabel return Pefindo 25 dapat dijelaskan oleh variabel makroekonomi yang digunakan dan sisanya sebesar $24,42 \%$ dijelaskan oleh variabel-variabel lain di luar model. Pengaruh faktor makroekonomi terhadap return Pefindo 25 pada Tabel 2. Pada model return Pefindo 25 pengaruh BI Rate sebesar 2,695449, hasil ini menunjukan return Pefindo 25 akan meningkat sebesar $2,695 \%$ bila nilai BI Rate meningkat sebanyak $1 \%$, hasil pengaruh positif dari BI Rate ini sesuai dengan penelitian Hasan (2010), Butt et al. (2010), serta Benakovic dan Posedol (2010), menyebutkan tingkat suku bunga berpengaruh positif terhadap return saham.

Tabel 2. Pengaruh faktor makroekonomi terhadap return Pefindo 25

\begin{tabular}{lcccc}
\hline Variable & Coefficient & Std. Error & t-Statistic & Prob. \\
\hline C & 8,836625 & 1,789083 & 4,939193 & 0,0000 \\
BI & 2,695449 & 0,754576 & 3,572139 & $0,0009^{* *}$ \\
KURS & $-1,016417$ & 0,669986 & $-1,517071$ & 0,1369 \\
IHK & 7,012527 & 2,620526 & 2,675999 & $0,0107^{* *}$ \\
GOLD & 0,208445 & 0,378042 & 0,551381 & 0,5844 \\
OIL & 1,328537 & 0,213613 & 6,219372 & $0,0000^{* *}$ \\
\hline
\end{tabular}

*) nyata pada taraf $10 \%$;*) nyata pada taraf $5 \%$ 
Hamdy (1998) menyatakan foreign currency adalah mata uang asing atau alat pembayaran lainnya yang digunakan untuk melakukan atau membiayai transaksi ekonomi keuangan internasional dan yang mempunyai catatan kurs resmi pada bank Sentral. Hasil kedua menunjukan hubungan antara return Pefindo 25 dengan nilai kurs tukar Rupiah-Dollar AS dipengaruhi sebesar 1,016417, hal ini menunjukan bila kurs tukar meningkat sebesar $1 \%$ maka return Pefindo 25 akan menurun sebesar $1,016 \%$, tetapi yang dipengaruhi secara negatif. Pefindo 25 tidak dipengaruhi secara signifikan oleh perubahan harga kurs. Pengaruh negatif dan tidak signifikan kurs pada return Pefindo 25 ini sesuai dengan penelitian yang dilakukan oleh Butt et al. (2010), Herve et al. (2011), dan Damayanti (2011).

Indeks Harga Konsumen dapat digunakan sebagai perwakilan dari inflasi, karena inflasi menyebabkan harga bahan baku meningkat dan pergeseran kebutuhan masyarakat menjadi kebutuhan konsumsi sehingga menyebabkan harga saham menjadi turun (Benakofic dan Posedol, 2010) dan diperkuat oleh penelitian Mubarok (2014) dan Utami (2015). Hasil dari penelitian ini menemukan bahwa indeks harga konsumen berpengaruh positif pada return Pefindo 25 dipengaruhi sebesar 7,012527 , pengaruhi ini menunjukan jika Indeks Harga Konsumen meningkat sebanyak $1 \%$ return Pefindo 25 akan meningkat sebanyak 7,01\%. Hasil ini berlawanan dengan hasil yang diutarakan oleh Benakofic dan Posedol (2010) dimana Indeks Harga Konsumsi berpengaruh negatif pada return.Sebaliknya, hasil ini sesuai dengan penelitian yang dilakukan oleh Victor dan Kuwornu (2011), Herve et al. (2011), dan Eita (2012) yang menunjukan Inflasi berpengaruh positif dan signifikan.

Faktor makroekonomi berikutnya yang memengaruhi return Pefindo 25 dipengaruhi secara positif oleh harga emas. Return Pefindo 25 dipengaruhi sebesar 0,208445, hasil ini menunjukan return dari Pefindo 25 akan naik sebesar $0,208 \%$ bila harga emas menigkat sebanyak $1 \%$. Tetapi harga emas tidak berpengaruh signifikan.

Return dari Pefindo 25 dipengaruhi secara positif oleh harga minyak Brent. Return Pefindo 25 dipengaruhi sebesar 1.328537. Hasil ini menunjukan kenaikan harga minyak Brent akan menaikan return LQ 45 sebesar 0,171\%, dan return Pefindo 25 akan naik sebesar $1,329 \%$ bila harga minyak Brent naik $1 \%$. Kilian dan Park (2007) melakukan penelitian yang hasilnya adalah apabila kenaikan harga minyak dunia disebabkan oleh meningkatnya permintaan minyak dunia akibat ketidakpastian ketersediaan minyak di masa depan, maka hal ini akan membawa pengaruh negatif bagi pasar modal. Namun, apabila meningkatnya harga minyak dunia disebabkan oleh peningkatan perekonomian, maka akan memberikan dampak positif bagi pasar modal. Kegiatan ekonomi indonesia terus bertumbuh dilihat dari meningkatnya pertumbuhan ekonomi Indonesia pada tahun 2015 sebesar 4,9\% menjadi 5,0\% pada tahun 2016 menunjukan pertumbuhan ekonomi tersebut ditopang oleh konsumsi swasta (Bank Indonesia, 2017)

\section{Saran Pengambilan Keputusan Investasi}

Investoryang tertarikpada perusahaan dengan kapitalisasi besar sebaiknya memperhatikan faktor makroekonomi, yakni BI Rate, Kurs tukar Rupiah-Dollar AS, harga emas dunia, dan harga ninyak Brent untuk menetuka besarnya return yang diharapkan. Investor yang melakukan investasi dalam indeks LQ 45 dapat melihat bila ada berita kenaikan dari BI Rate dan harga minyak brent sebaiknya menahan atau menambah investasi yang dilakukannya untuk memperbesar keuntungan yang mungkin akan diperoleh dan bila terjadi penurunan BI Rate ataupun harga minyak Brent investor sebaiknya bersiap-siap mengurangi atau menahan investasinya sampai kondisi yang menguntungkan bagi investor. Kurs tukar rupiah memilik pengaruh negatif bagi return LQ 45 hal ini dapat digunakan oleh investor yang berinvestasi dalam LQ 45 dapat melihat bila ada kenaikan kurs tukar, return yang akan diperoleh investor akan mengecil. Pengaruh ini dapat digunakan oleh investor untuk mengurangi kerugian yang akan diperolehnya dalam berinvestasi pada LQ 45.

Investor yang tertarik dalam melakukan investasi pada perusahaan kecil dan menegah lebih baik memperhatikan BI Rate, Indeks Harga Konsumen, harga minyak Brent sebagai variabel makroekonomi yang dipertimbangkan dalam penentuan return yang diharapkan pada investasi di Pefindo25. Indeks Pefindo 25 lebih cocok untuk investor yang mau menerima tingkat kerugian yang besar untuk mendapatkan keuntungan yang lebih. Pada indeks Pefindo 25 variabel-variabel makroekonomi memiliki pengaruh yang positif sehingga kenaikan salah satu variabel makroekonomi terutama Indeks Harga Konsumen sebaiknya segera direspon oleh investor dengan menambah jumlah investasi yang ditanamkan dalam Pefindo 25 untuk memperbesar keuntungan yang akan diperoleh dalam investasinya. 
Bagi investor yang ingin menciptakan portofolio yang terdiri dari indeks LQ 45 dan Pefindo 25 variabel makroekonomi yang perlu diperhatikan adalah BI Rate dan harga minyak Brent sebagai variabel makroekonomi utama yang digunakan untuk menentukan besarnya harapan keuntungan dari investasi, dan variabelvariabel makro ekonomi lain seperti Kurs tukar RupiahDollar As, Indeks Harga Konsumen, dan harga emas dapat digunakan sebagai tambahan dalam pengambilan keputusan investasi

\section{Implikasi Manajerial}

Hasil yang telah diperoleh dalam penelitian ini dapat dimunculkan implikasi manajerial kepada beberapa pihak yaitu investor sebagai pihak yang melakukan investasi dan regulator dalam hal ini pemerintah untuk meciptakan iklim investasi yang baik. Pada penelitian ini menunjukan bahwa baik pada indeks kapitaslisasi besar yakni LQ 45 maupun pada indeks kapitalisasi kecil dan menengah Pefindo 25, dipengaruhi oleh dua variabel makroekonomi secara positif yakni BI Rate dan harga minyak Brent, dari kedua variabel makroekonomi yang memengaruhi return kedua indeks tersebut indeks Pefindo 25 dipengaruhi lebih besar bila dibandingkan dengan pengaruh kedua variabel makroekonomi terhadap return LQ 45, dengan hasil ini diharapkan bagi para investor yang melakukan investasinya pada dua indeks tersebut untuk memperhatikan BI Rate dan Harga minyak Brent sebagai landasan dalam pengambilan keputusan investasi yang dilakukan.Tambahan lain sebagai pertimbangan investasi bila investor tertarik untuk berinvestasi pada indeks perusahaan kecil dan menengah, yakni Pefindo 25 adalah Indeks Harga Konsumen yang berpengaruh positif dengan naiknya IHK akan meningkatkan return yang bisa diperoleh dalam investasi pada indeks Pefindo 25.

\section{KESIMPULAN DAN SARAN}

\section{Kesimpulan}

Sepanjang periode penelitian dari Januari 2010 sampai dengan Desember 2017, pergerakan tingkat BI Rate, harga emas, dan harga minyak Brent memiliki pengaruh positif dan signifikan terhadap return LQ 45. Kurs nilai tukar Rupiah-Dollar AS berpengaruh secara negatif dan signifikan terhadap return LQ 45. Indeks Harga Konsumen tidak berpengaruh secara signifikan pada indeks. Return Indeks Pefindo 25 dipengaruhi secara positf dan signifikan oleh BI Rate, Indeks Harga Konsumen, dan harga minyak Brent. Keputusan investasi yang dibuat investor yang bisa menerima resiko besar untuk memperoleh keuntungan besar sebaiknya melakukan investasi pada saham pada pefindo 25, dengan memperhatikan pergerakan Indeks Harga Konsumen yang pada penelitian ini memberikan efek yang paling besar pada return dari Pefindo 25 . Return LQ 45 lebih ditujukan kepada investor yang melakukan investasi pada saham-saham berkapitalisasi besar yang cenderung stabil dilihat dari pengaruh faktor makroekonomi. Faktor makroekonomi yang memengaruhi paling besar adalah nilai kurs tukar, investor yang berinvestasi pada LQ 45 memperhatikan nilai kurs tukar untuk bisa mengurangi kerugian yang mungkin akan diterima jika terjadi perubahan pada kurs tukar.

\section{Saran}

Periode penelitian menggunakan data bulanan, untuk menunjukan hasil yang lebih akurat penelitian selanjutnya lebih baik menggunakan periode mingguan dalam pencarian variabel-variabel yang digunakan. Peniltian membatasi pada BI Rate, Kurs tukar, Indeks Harga Konsumen, Harga Emas dunia, Harga minyak Brent. Penelitian berikutnya diharapkan mampu menambah variabel makroekonomi yang ada untuk memperkaya hasil dan menjelaskan lebih jelas pengaruh variabel makroekonomi terhadap return saham.

\section{DAFTAR PUSTAKA}

Benakovic D, Posedel P. 2010. Do macroeconomic factors matter for stock returns? Evidence from estimating a multifactor model on the Croacian market. Business System Research 1(1-2): 3946

Butt BZ, Rehman KU, Khan MA, Safwan N. 2010. Do economic factors influence stock returns? A firm and industry level analysis. African Journal of Business Management 4(5):583-593.

Damayanti SM. 2014. Analisis pengaruh variabelvariabel makroekonomi terhadap tingkat pengembalian di pasar modal periode 2000-2011 dengan membandingkan hasil estimasi ols, GLS DAN MLE. Binus Business Review 5 (1): 267 277. https://doi.org/10.21512/bbr.v5i1.1215.

Eita JH. 2012. Inflation and stock market returns in South Africa. The International Business dan 
Economics Research Journal 11(6):677-686. https://doi.org/10.19030/iber.v11i6.7020.

Eita JH. 2014. Interest rate and stock market returns in Namibia. The International Business dan Economics Research Journal 13(4):689-696. https://doi.org/10.19030/iber.v13i4.8677.

Fatima T, Bashir A. 2014. Oil price and stock market fluctuations: emerging markets (a comparative study of Pakistan and China). International Review of Management and Business Research. 3(4):1958-1976.

Hasan. 2010. Analisis pengaruh return pasar dan beberapa variabel makro ekonomi terhadap return saham individual dan portfolio. AKSES: Jurnal Ekonomi dan Bisnis 5(9): 97-107.

Hasan MM. 2011. Sector-wise stock return analysis: an evidence from Dhaka stock exchange in Bangladesh. International Journal of Business and Management 6(6): 276-285.

Handiani S. 2014. Pengaruh harga emas dunia, harga minyak dunia dan nilai tukar dolar amerika/ rupiah terhadap indeks harga saham gabungan pada periode 2008-2013. E-journal Graduate UNPAR1(1): 85-93.

Herve DBG, Chanmalai B, Shen Y. 2011. The study of causal relationship between stock market indicies and macroeconomic variables in Cote d'Ivoire: evidence from error-correction models and granger causality test. International Journal of Business and Management 6(12): 146-169. https://doi.org/10.5539/ijbm.v6n12p146.

Horng W, Huang M. 2014. Threshold model of gold and oil price volatility in southeast asia two stock markets: empirical study of thailand and malaysian countries. International Review of Management and Business Research 3(3): 1408-1415.

Kilian L, Cheolbeom P. 2007. The impact of oil price shocks on the u.s. stock market. International Economic Review 50(4):1-46.
Kuwonru JKM, Victor ON. 2011. Macroeconomic variables and stock market returns: Full information maximum likelihood estimation. Research Journal of Finance and Accounting 2(4):49-63.

Mubarok F. 2014. Analisis pengaruh kinerja keuangan dan variabel makroekonomi terhadap return saham subsektor perkebunan. [tesis]. Bogor: Institut Pertanian Bogor.

Monjazeb M, Shakerian MS. 2014 The effects of gold price and oil price on stock returns of the banks in Iran. Arabian Journal of Business and Management Review (OMAN Chapter) 3(9).

Phoong SW, Ismail MT, Sek SK. 2013. A markov switching vector error correction model on oil price and gold price effect on stock market returns. Information Management and Business Review 5(7):331-336.

Prasetiono DW. 2010. Analisis pengaruh faktor fundamental ekonomi makro dan harga minyak terhadap Saham LQ 45 dalam jangka pendek dan jangka panjang. Journal of Indonesian Applied Economics 4(1): 11-25.

Suwandy T. 2014. Analisis pengaruh inflasi, nilai tukar, bi rate, harga minyak dunia, harga emas dunia, dan indeks straits times terhadap return indeks LQ 45 pada bursa efek indonesia tahun 20032013. Jurnal Bisnis dan Strategi 23(1): 43-58.

Switzer LN. 2012. The relative performance of small cap firms and default risk across the business cycle: international evidence. International Journal of Business 17(4): 379-396.

Vanita T, Khushboo A. 2015. Long run co-integrating relationship between exchange rate and stock prices: empirical evidence from BRICS Countries. Advances in Management 8(1):1525.

Utami WR. 2015. Pengaruh faktor internal dan eksternal terhadap return saham subsektor konstruksi. [tesis]. Bogor: Institut Pertanian Bogor. 